\title{
Accompaniment for Supplying the Chain in the Marketing of Sweet Potato (Ipomea batatas L)
}

\author{
Farida Mardhatilla ${ }^{a}$, Edy Hartono, and Firman Hidayat \\ Universitas Swadaya Gunung Jati, Cirebon, Indonesia \\ Corresponding author: fmardhatilla@gmail.com
}

\begin{abstract}
Kuningan Regency is the area that has potential in agriculture. One of the leading commodities in Kuningan Regency is sweet potato (Ipomea batatas L). Sweet potato cultivation continues to be developed, even in Cilimus District, it is known as one of the productive production centers in the West Java region which provides sweet potato supplies to several areas to supply sweet potato needs in the West Java region. The problems are faced by farmers today including the increasingly erratic price of sweet potatoes, lack of market opportunities, product diversification, and mastery of cultivation technology. This service activity was carried out in Cilimus Village, Cilimus District, Kuningan Regency with partners of sweet potato farmers. The purpose of this assistance is to provide supply chain assistance for sweet potato marketing so that farmers are able to continuously market sweet potatoes above the production price. Mentoring activities were started from identification of sweet potato problems at the farmer level, identification of production and identification of markets. The using of method is interactive discussion and market mapping conducted together with farmers. Focus Group Discussion (FGD) was used to confirm the cultivation system, production, and marketing system of sweet potato. The result of this activity is that farmers know the marketing potential of sweet potatoes other than middlemen and the quality criteria of sweet potatoes according to industry demand. In addition, farmers also use sweet potatoes as animal feed.

Keywords: Mentoring, sweet potato, marketing.
\end{abstract}

\section{INTRODUCTION}

Sweet potato (Ipomoae batatas L.) is the secondary crop commodity that contains carbohydrates with a low glycemic index of 54 , making it suitable for consumption by diabetics. Sweet potato is widely cultivated in West Java. Kuningan Regency is one of the regencies in West Java Province which is one of the sweet potato producing centers. The sweet potato processing industry into pasta has been marketed to Japan and Korea. This proves that sweet potato has a high economic value.

Sweet potato production in Kuningan Regency is spread over 9 (nine) sub-districts around Mount Ciremai, including Cilimus, Darma, Kadugede, Cigugur, Kuningan, Kramatmulya, Jalaksana, Mandirancan and Pesawahan sub-districts. Of the 9 (nine) sub-districts, based on the Kuningan District Regulation in 2005, the sweet potato center included in the Agropolitan master plan is centered in Cilimus District. Cilimus sub-district has 13 villages, including Cilimus village.

Sweet potato varieties that are generally cultivated in Kuningan Regency are the red and white Anak Ciremai $(A C)$ varieties. At first the variety was a local variety of Kuningana area. However, in 2008 the Ministry of Agriculture determined the local variety of AC to be the national sweet potato variety and changed its name to Kuningan Merah and Kuningan Putih varieties.(1)

The conventional sweet potato cultivation system with inorganic fertilizer application (Urea, SP$36, \mathrm{KCL}, \mathrm{NPK}$ ) still dominates. The addition of organic matter in the form of manure and compost has not been carried out with consideration of heavy soil texture (clay) which is able to absorb water, so it is feared that it will accelerate the rotting of tubers due to the high water content of the soil.

In addition to the use of fertilizers, the absence of regulation of cropping patterns causes an abundant supply of sweet potatoes at harvest. The abundance of harvested tubers has an impact on the accumulation of sweet potatoes on farmers' land because not all sweet potatoes can be absorbed by local and industrial markets. Farmers prefer not to harvest sweet potatoes that are 
ready to harvest, because the low income they receive cannot cover the high production costs including labor.

The sweet potato marketing system in the Cilimus area is mostly done by conventional systems. Farmers will sell the harvest they get to middlemen with a buying price range of Rp. 400, - up to Rp 2,500, - for every kilo gram. The low purchase price received by farmers, especially when there is excess production, causes the bargaining position of farmers to be low. This could potentially reduce the interest of farmers to cultivate sweet potatoes and switch to other commodities.

Product diversification efforts have also not been done much for increasing the added value of sweet potatoes. Generally, sweet potatoes are sold in fresh form to meet the needs of local and industrial markets. Only a small number of farmers or the surrounding community use sweet potatoes that are not suitable for consumption/kulanas/boleng as animal feed ingredients.

Given the high potential of the Cilimus Village area as a production center for sweet potato commodities, it is necessary to develop a comprehensively managed cultivation system. The purpose of the management is to obtain the continuity of sweet potato production which is able to provide maximum profit for farmers.

The basic problems that are occured in sweet potato farmers in Cilimus village can be divided into cultivation and marketing problems. On the cultivation side, the problem faced is the irregularity of the sweet potato cropping pattern system. The results of the assessment with the sweet potato processing industry that utilizes sweet potato as the main raw material, indicate that in order to meet the product criteria, it is necessary to guarantee the continuity of production with the required quality. The product criteria required are yams that are not deformed/boleng/kulanas, have a low water content, and a maximum harvest time of 3 days.

Meanwhile, from the marketing side, the classic problem faced is the low purchase price at the farmer level, especially when the product is abundant. Apart from being sold directly to meet the local market, sales are only made to middlemen with uncertain prices and delayed or indirect payment systems. This means that farmers only get the sales results in the form of money after the middlemen market the sweet potatoes. This causes the bargaining position of farmers to be low.

The uncertainty of market and industry acceptance and prices causes farmers to be less motivated to improve the quality of sweet potato production. The income received has not been able to cover the high cost of production and labor. Post-harvest management has not been maximized, market potential and uncertain prices have caused farmers to prefer not to harvest the planted sweet potatoes or switch to other commodities such as rice that are more promising. This is of course contrary to the government's goal to improve the welfare of sweet potato farmers.

From the problems above, the service team is trying to find the best solution so that farmers can continue to produce and not suffer losses by providing assistance to the industrial market and assisting the application of cropping patterns on sweet potato farmers' land in Cilimus Village..

\section{METHOD}

This Community Service activity was carried out in April 2021 in Cilimus Village, Kuningan Regency. Activity planning includes initial discussions with sweet potato farmers around Cilimus Village. Forum Group Discussion (FGD) was conducted to dig deeper into the problems faced by sweet potato farmers related to sweet potato cultivation habits by farmers, varieties planted, production and productivity of sweet potato, and marketing system.

Implementation of Community Service (PKM) which was carried out by conducting a survey on two processing industries made from sweet potato in Cirebon Regency. The results of the survey were conveyed to farmers so that farmers understand sweet potato varieties and product criteria that can be absorbed for the sweet potato processing industry. Furthermore, assistance is provided for farmers who want to apply a healthy sweet potato cultivation pattern on their land. The results of the activities evaluated include internal assessments of the success of the implemented programs as well as analyzing the problems encountered in the implementation of PKM activities. 


\section{RESULT}

The activities that have been carried out are adjusted to the methods that are carried out. Based on surveys and Forum for Group Discussion's that have been carried out with sweet potato farmers in Cilimus village, $\mathrm{t}$

Then the following results are obtained:

1. There are still many sweet potatoes with poor quality due to kulanas disease in sweet potato harvests.

2. Counseling from the PKM team on sweet potato cultivation was found that some farmers did not understand deeply about the causes and efforts to overcome kulanas or boleng disease that attacks sweet potatoes.

3. The results of the inventory or data collection show that the area of sweet potato harvested land in 2020 will reach 1,093 hectares with a productivity rate of 62,301 tons.

4. A survey on two sweet potato processing industries in Cirebon Regency that utilizes sweet potato as the main raw material, resulted in information that there is a need for sweet potatoes with certain criteria for types or varieties of sweet potatoes. These criteria include, sweet potatoes are white, have low water content, are not peeled/bolenged and sweet potatoes that are processed are fresh sweet potatoes (3 days after harvest). The cassava processing industry needs up to 30 tons per day.

5. In general, sweet potato farmers in Cilimus Village are interested in the program that was offered by the PKM Team.

\section{DISCUSSION}

Sweet potatoes have high market to be prospected because apart from their nutritional and functional properties, sweet potatoes also have great potential to be developed in an effort to diversify food consumption (2). This potential has been realized by partner farmers, but farmers must produce sweet potatoes with the required quality criteria. One of the factors that can determine the quality of sweet potatoes is a better cultivation system (3). The sweet potato cultivation system with the addition of organic fertilizer can be carried out by farmers in addition to inorganic fertilizers that have been carried out so far. In addition, the pattern of planting time can be applied to sweet potato cultivation.

Based on observations in the field at harvest time, there are still many sweet potatoes that fail to harvest due to sweet potatoes that are attacked by kulanas disease. The PKM team has conducted counseling on how to cultivate sweet potatoes better in order to avoid pests and diseases such as kulanas/boleng. However, this has not yet been implemented because the sweet potato commodity from some of the partner farmers has been harvested.

The PKM team has conveyed the results of a survey on the sweet potato processing industry to partner farmers about the potential demand for sweet potatoes for the industry, of course sweet potatoes with certain quality criteria with a sustainable supply. Submission of the results of this survey is intended so that farmers can understand the needs of the industry so that they can produce sweet potatoes with quality criteria as required.

Generally, sweet potato farmers in Cilimus Village are interested in the program offered by the PKM Team. However, for now on , most of the sweet potatoes planted have been harvested and farmers are in the stage of raising capital for further land cultivation. So that in the next planting period, farmers can apply a good sweet potato cultivation system including compiling a pattern of planting time to produce sweet potatoes with the required criteria and sustainable production in order to meet industrial needs.

One of the outcomes to be achieved from the implementation of this PKM is cooperation in the sale of sweet potatoes between partner farmer groups and the sweet potato processing industry through assistance from the PKM team. However, this has not been achieved because the sweet potatoes produced by partner farmers still do not meet the criteria for industrial needs. In addition, the guarantee of the sustainability of sweet potato supply cannot be ascertained because the 
harvest time is uncertain which is determined by the pattern of planting time.

The solution provided by the PKM team is for farmers to collaborate with the sweet potato supplier team in the processing industry as one of the sweet potato suppliers. The stage of cooperation with sweet potato suppliers is underway. The purpose of this collaboration is to provide market opportunities for sweet potato farmers and improve sweet potato cultivation. In addition to the stage of cooperation with sweet potato suppliers, another solution provided by the PKM team is processing sweet potatoes as animal feed(4)(5)(6).

The potential of sweet potato as animal feed is very promising. Sweet potato can be used as feed for pigs (6), rabbit feed (5) and small ruminant feed (4).

\section{CONCLUSIONS AND SUGGESTIONS}

This PKM activity can be concluded as follows:

1. Although some farmers have been cultivating sweet potatoes for a long time, the knowledge of farmers regarding sweet potato cultivation, including pests and diseases, is not fully understood.

2. The lack of price and market certainty is one of the reasons for the low quality of sweet potatoes produced.

3. Cooperate with the sweet potato supplier team to the industry as a supplier.

4. Animal feed processing is the right solution at this time for farmers.

Suggestions that can be given for this PKM activity is the need for cultivation assistance for sweet potato farmers to improve the quality of sweet potatoes so as to produce sweet potatoes that can be absorbed by the industry with high economic value. In addition, local government policies on sweet potato marketing are also expected to sustain farmers' production.

\section{ACKNOWLEDGMENTS}

We thank for all parties who have collaborated and supported the implementation of Community Service. Thank you to the Gunung Jati University Community Service Institute (LPM-UGJ) and the Cilimus Village Government, Cilimus District, Kuningan Regency, especially to the sweet potato farmers who have participated in this activity.

\section{REFERENCES}

Department of Agriculture. Agricultural Profile of Kuningan Regency. 2006.

Widowati S. Diversification of Sweet Potato-Based Food Consumption. J Food. 2010;20(1):49-61. Widodo Y. Practical Sweet Potato Cultivation Technology Supports Food Security and Agroindustry. Bul Palawija. 2014;0(17):21-32.

Sirait J, Simanihuruk K. Potential and Utilization of Cassava and Sweet Potato Leaves as Feed Source for Small Ruminants. Wartazoa. 2010;20(2):75-84.

Aumont O, Pierre U, Marie ET, Paris C, Gómez-Letona M, Ramos AG, et al. No Title No Title No Title. Biogeosciences [Internet]. 2018;43(5):679-94. Available from: http://www.unil.ch/ssp/page34569.html

Limbongan J, Soplanit A. Technology availability and development potential of sweet potato (Ipomoea batatas L.) in Papua. J R \& D Pertan. 2007;26(4):131-8.

Suismono. Processing technology and utilization of local food based on tubers. $J$ Food. 2008;(52):38-50.

Central Bureau of Statistics of Kuningan Regency. Sweet Potato Production [Internet]. 2015. Available from: https://kuningankab.bps.go.id/statictable/2015/04/30/26/hasil-tanamanpangan-padi-dan-palawija-2011.html 
APPENDIX

Table 1. Nutritional Content in White Sweet Potato and Yellow Sweet Potato

\begin{tabular}{llll} 
No. & \multicolumn{1}{c}{ Contents } & \multicolumn{2}{c}{ Amount in } \\
\cline { 3 - 4 } & & $\begin{array}{r}\text { Yellow } \\
\text { Sweet } \\
\text { Potato }\end{array}$ & $\begin{array}{c}\text { Yellow } \\
\text { Sweet } \\
\text { Potato }\end{array}$ \\
\hline 1. & Calories (cal) & 123,00 & 136,00 \\
2. & Protein (gr) & 1,80 & 1,10 \\
3. & Fat & 0,70 & 0,40 \\
4. & Carbohydrate (gr) & 27,90 & 23,30 \\
5. & Air (gr) & 68,50 & - \\
6. & Coarse fiber & 0,90 & 1,40 \\
7. & Sugar content & 0,40 & 0,30 \\
8. & Beta carotene & 31,20 & - \\
\hline
\end{tabular}

Sumber : (7)

Table 2. Sweet Potato Production in Cilimus . District

\begin{tabular}{llcccc}
\hline No. & Komponen Produksi & $\mathbf{2 0 0 9}$ & $\mathbf{2 0 1 0}$ & $\mathbf{2 0 1 1}$ & $\mathbf{2 0 1 2}$ \\
\hline 1. & Harvest Area $(\mathrm{Ha})$ & 2.394 & 1.561 & 2.116 & 1.883 \\
2. & Production $(\mathrm{Kw})$ & 425.850 & 279.510 & 425.132 & 370.960 \\
3 & Productivity $(\mathrm{Kw} / \mathrm{Ha})$ & 181,29 & 179,06 & 200,91 & 202,38 \\
\hline
\end{tabular}

Sumber : (8)

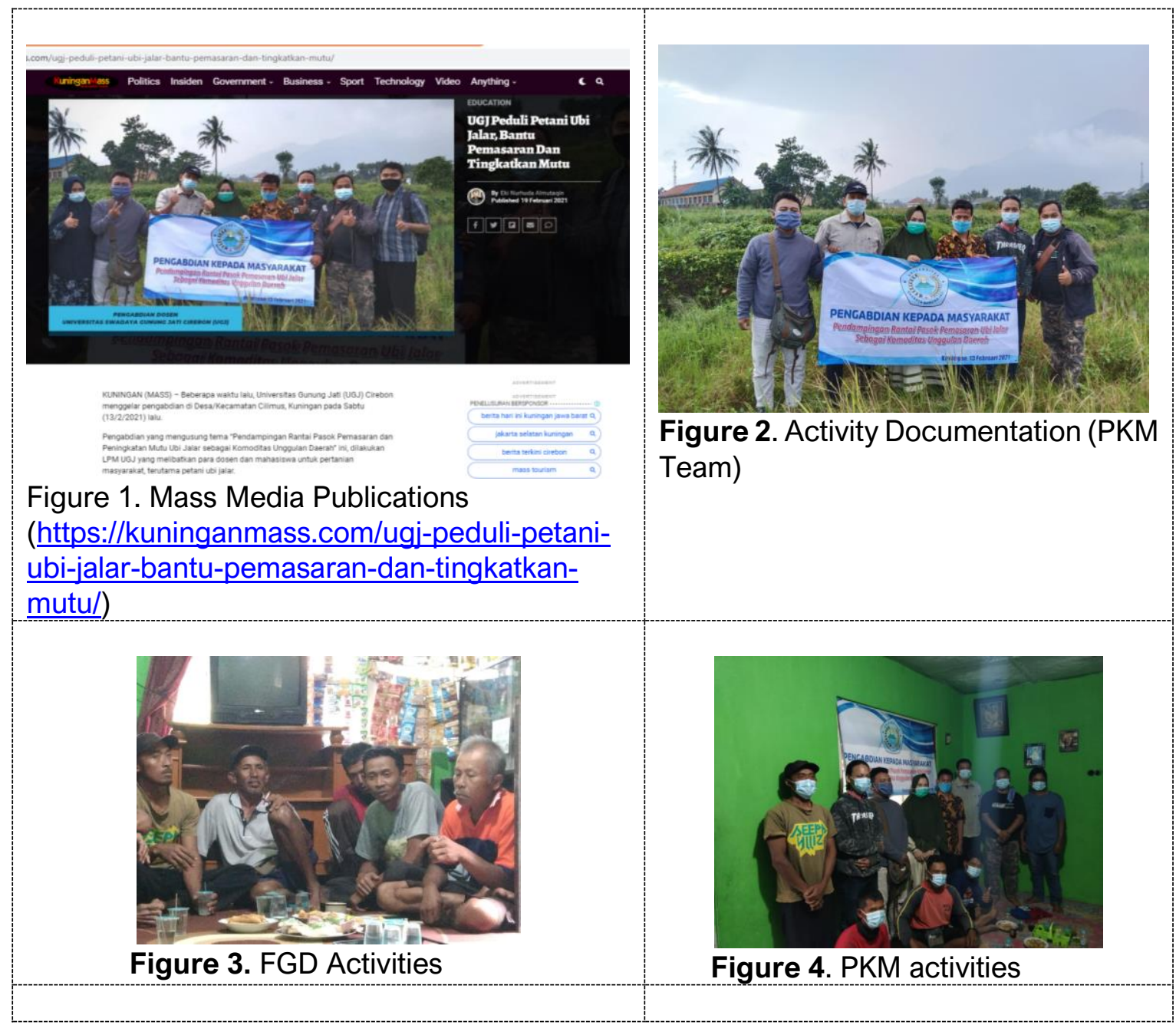




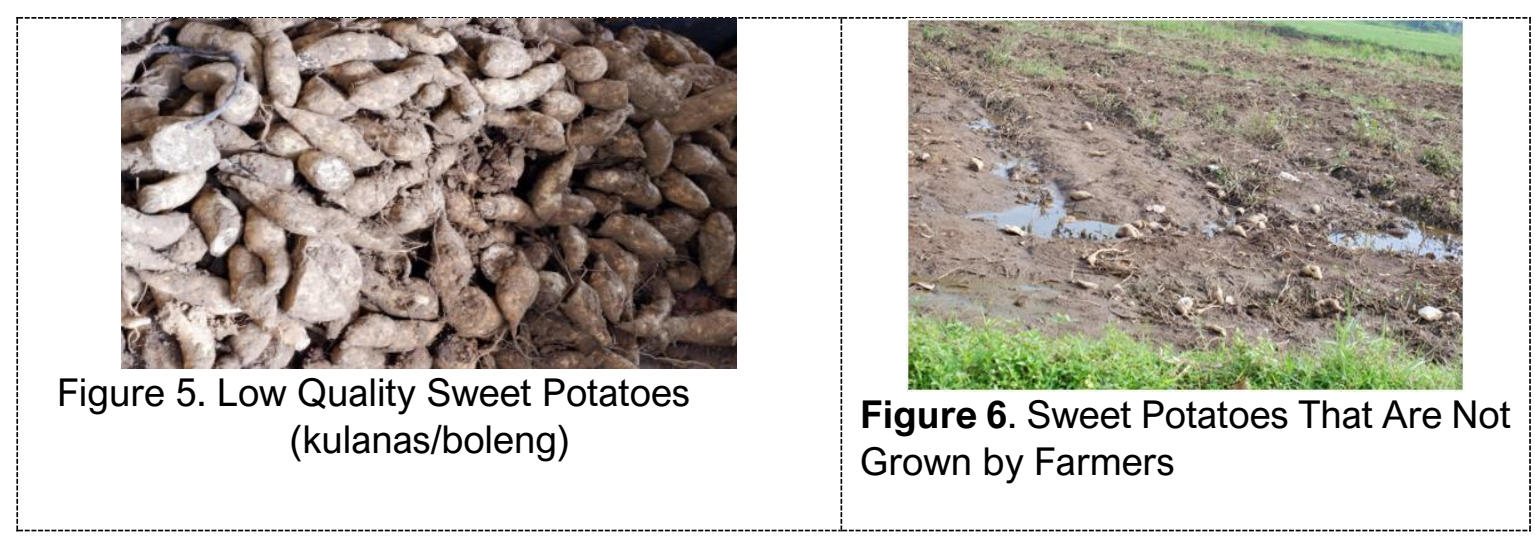

